NASZA DERMATOLOGIA Online OUR DERMATOLOGY Online

Source of Support: Nil

Competing Interests: None

\section{THE MEN BEHIND THE EPONYMOUS PHARMACEUTICALS COMPANIES}

\author{
Khalid Al Aboud ${ }^{1}$, Daifullah Al Aboud ${ }^{2}$ \\ ${ }^{1}$ Department of Public Health, King Faisal Hospital, Makkah, Saudi Arabia \\ ${ }^{2}$ Dermatology Department, Taif University, Taif, Saudi Arabia
}

Corresponding author: Dr. Khalid Al Aboud

amoa65@hotmail.com
There are different sources of names in medical field. Similarly, the names given to pharmaceuticals companies are derived from different things.

Selecting a good name is not always easy. In fact, there are now professional companies to help finding proper names for medical organizations and medications [1].

These were of help in naming pharmaceutical companies. For instance; "Zeneca" was an invented name created by the branding consultancy Interbrand. Interbrand had been instructed to find a name which began with a letter from either the top or bottom of the alphabet and was phonetically memorable, of no more than three syllables and did not have an offensive meaning in any language.

However, using the names of the founders (eponyms) is a common type of naming pharmaceuticals companies. In Table I [2-12], we highlighted on selected eponymous pharmaceuticals companies.

We want to stress on the fact that, the men behind pharmaceuticals companies deserve a special attention. Their success stories are educational and a source of inspiration for all the generations.
Their histories are worth to be incorporated to medical curriculum.

Patience, perseverance, donations, helping their communities and world as well as many other good things is to be learnt from their stories.

For example; Abbott, in his starts while working in his kitchen, measured his drugs into small pills he called „dosimetric granules", providing a more accurate dosage and a more effective, long-lasting drug than other medicines available at the time [2].

Dr. Upjohn, on the other hand, began experimenting with making better pills in the attic of his home. Eventually he invented his „friable" pill. Friable meant that the pill could easily be crushed to a powder [12].

The most recently lost one of these giants, is Pierre Fabre. He established, Pierre Fabre Foundation which was recognized as a public utility in 1999 and its mission is to help third-world countries to obtain quality drug, ensure better quality control of drugs, use local therapeutic resources and train scientists for the inspection of drugs [11].

\begin{tabular}{|c|l|}
\hline $\begin{array}{c}\text { Eponymous pharmaceutical } \\
\text { companies }\end{array}$ & \multicolumn{1}{c|}{ Remarks } \\
\hline Abbott Laboratories [2] & $\begin{array}{l}\text { It is an American global pharmaceuticals and health care products company. The company } \\
\text { headquarters are in Abbott Park, North Chicago, Illinois. The company was founded by Chicago } \\
\text { physician Wallace Calvin Abbott (1857-1921), (Fig. 1), in 1888. In 2010, Abbott had over \$35 } \\
\text { billion in revenue. }\end{array}$ \\
\hline Bayer [3,4] & $\begin{array}{l}\text { Bayer AG is a German chemical and pharmaceutical company founded in, Germany in 1863. It } \\
\text { is headquartered in Leverkusen, North Rhine-Westphalia, and Germany and well known for its } \\
\text { original brand of aspirin. The company will be 150 years old on 1 August 2013. In 2011, It had } \\
\text { over } € 36.53 \text { billion in revenue. } \\
\text { It was founded by Friedrich Bayer (1825-1880), (Fig. 2). He founded the dyestuff factory } \\
\text { Friedrich Bayer along with Johann Friedrich Weskott in 1863 in Elberfeld. }\end{array}$ \\
\hline
\end{tabular}

Table I. Selected eponymous pharmaceutical companies. 


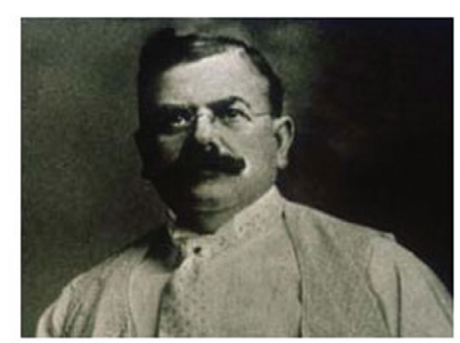

Wallace Calvin Abbott

Figure 1. Wallace C. Abbott (1857-1921).

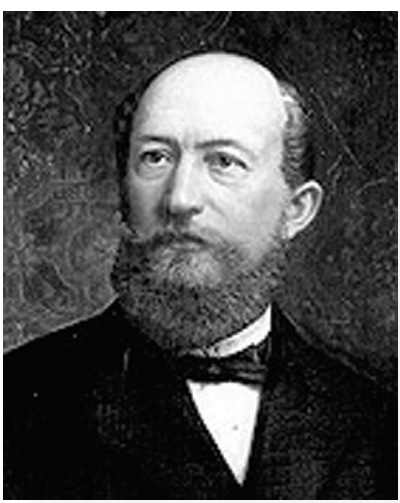

Figure 2. Friedrich Bayer (1825-1880).

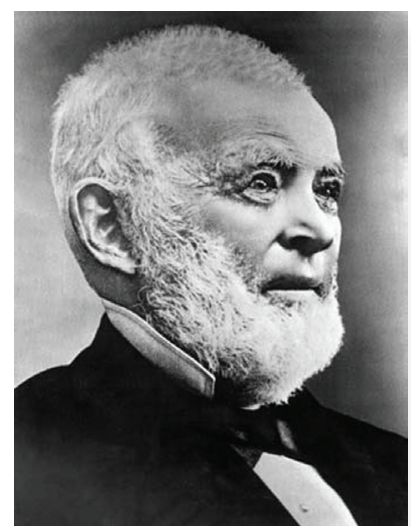

Figure 3. Edward Robinson Squibb (1819-1900).

\begin{tabular}{|c|l|}
\hline $\begin{array}{c}\text { Eponymous pharmaceutical } \\
\text { companies }\end{array}$ & \multicolumn{1}{c|}{ Remarks } \\
\hline Bristol-Myers Squibb [5,6] & $\begin{array}{l}\text { It is, often referred to as BMS, is a pharmaceutical company, headquartered in New York City. } \\
\text { The company was formed in 1989, following the merger of its predecessors Bristol-Myers and } \\
\text { the Squibb Corporation. In 2009, It had over US \$18.8 Billion in revenue. } \\
\text { Squibb was founded in 1858 by Edward Robinson Squibb (1819-1900), (Fig. 3), while Bristol- } \\
\text {-Myers was founded in 1887 by William McLaren Bristol (1860-1935), (Fig. 4), and John Ripley } \\
\text { Myers (1864-1899), (Fig. 5). }\end{array}$ \\
\hline Eli Lilly and Company [7] & $\begin{array}{l}\text { It is an American global pharmaceutical company with headquarters located in Indianapolis, } \\
\text { Indiana, in the United States. Their products are sold in approximately 125 countries. In 2011, } \\
\text { it had over US\$ 24.286 billion in revenue. The company was founded in 1876 by Col. Eli Lilly } \\
\text { (1838-1898), (Fig. 6), who was an American soldier, pharmaceutical chemist, and industrialist. }\end{array}$ \\
\hline Johnson \& Johnson [8,9] & $\begin{array}{l}\text { It is a U.S multinational medical devices, pharmaceutical and consumer packaged goods } \\
\text { manufacturer founded in 1886. It is headquartered in New Brunswick, New Jersey. Johnson \& } \\
\text { Johnson had worldwide sales of \$65 billion for the calendar year of 2011. } \\
\text { It is founded by three American American businessmen; Robert Wood Johnson I (1845-1910), } \\
\text { (Fig. 7), James Wood Johnson (1856-1932) and Edward Mead Johnson (1852-1934). }\end{array}$ \\
\hline Pfizer [10] & $\begin{array}{l}\text { It is an American multinational pharmaceutical corporation headquartered in New York City. } \\
\text { Pfizer was founded in New York City in 1849. It is named after the German-American cousins } \\
\text { Charles Pfizer (1824-1906), (Fig. 8), and Charles Erhart. Its revenue was estimated to be US\$ } \\
58.98 \text { billion (2012). }\end{array}$ \\
\hline Table I. Selected eponymous pharmaceutical companies (continued). \\
\hline
\end{tabular}

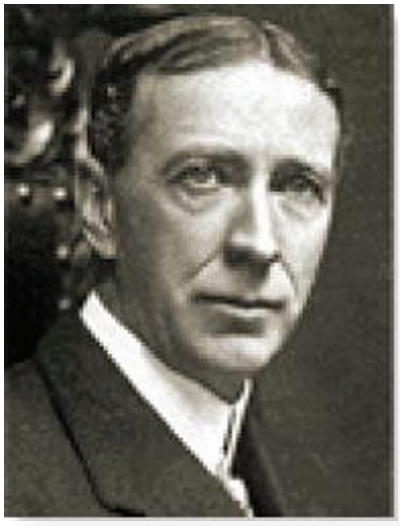

Figure 4. William McLaren Bristol (1860-1935).

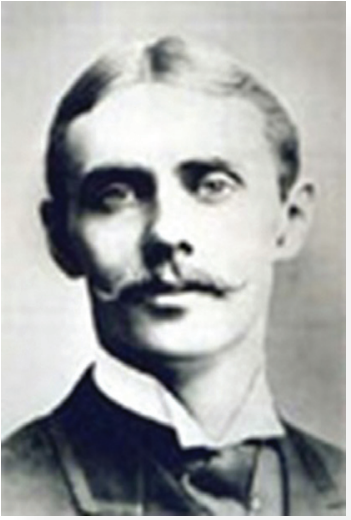

Figure 5. John Ripley Myers (1864-1899).

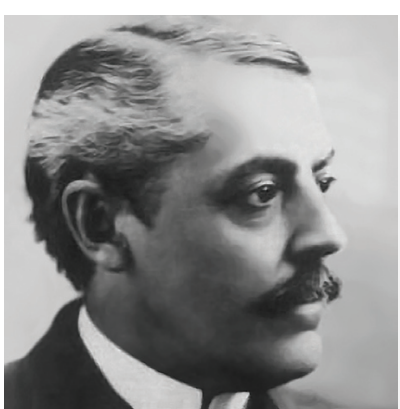

Figure 6. Eli Lilly (1838-898).

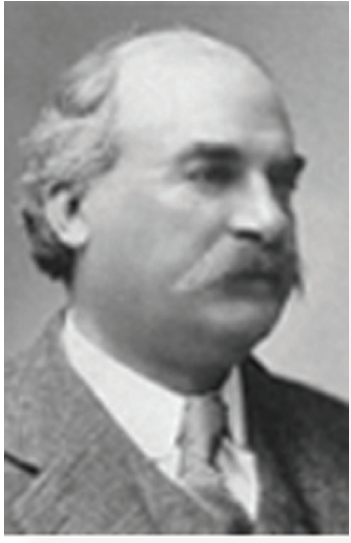

Figure 7. Robert Wood Johnson I (1845-1910). 


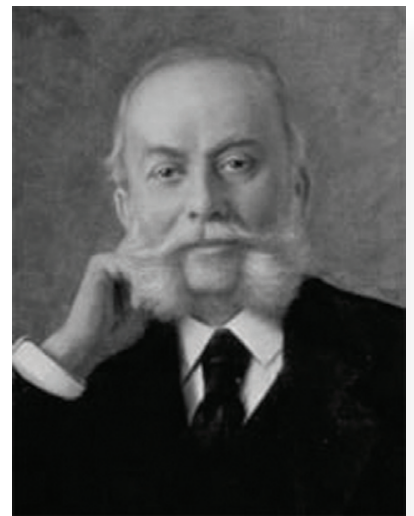

Figure 8. Charles Pfizer (1824-1906).

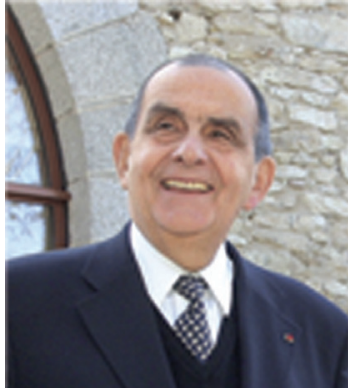

Figure 9. Pierre Fabre (1926-2013).

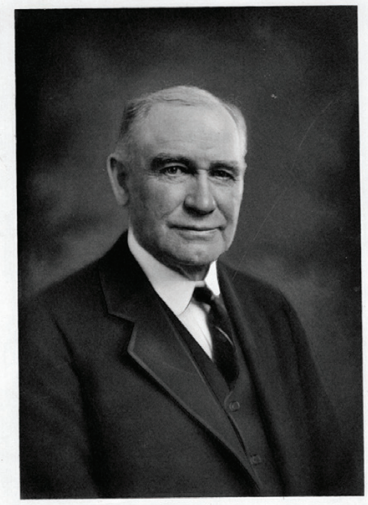

Wr ection

Figure 10. William Erastus Upjohn (1853-1932).

A courtesy of Kalamazoo Public Library.

\begin{tabular}{|c|l|}
\hline $\begin{array}{c}\text { Eponymous pharmaceutical } \\
\text { companies }\end{array}$ & \multicolumn{1}{c|}{ Remarks } \\
\hline Pierre FABRE laboratories [11] & $\begin{array}{l}\text { It is a multinational pharmaceutical and cosmetics company based in Castres, France, near } \\
\text { Toulouse. The company had a consolidated turnover of 1.978 billion euros in 2012. } \\
\text { Founded in 1962 by Pierre Fabre, it is present in over 130 countries and has more than 10,000 } \\
\text { employees (in 2012). } \\
\text { Pierre Fabre (1926-2013), (Fig. 9), was a French chemist. }\end{array}$ \\
\hline Upjohn [12] & $\begin{array}{l}\text { The Upjohn Company was a pharmaceutical manufacturing firm founded in 1886 in Kalamazoo, } \\
\text { Michigan by Dr. William E. Upjohn. The company was originally formed to make friable pills, } \\
\text { which were specifically designed to be easily digested. These could be ,reduced to a powder } \\
\text { under the thumb”, a strong marketing argument for the time. } \\
\text { In 1995, Upjohn merged with Pharmacia AB, to form Pharmacia \& Upjohn. Later the company } \\
\text { merged with Monsanto Company and took the name Pharmacia. } \\
\text { William Erastus Upjohn (1853-1932), (Fig. 10), was an American medical doctor, a graduate of } \\
\text { the University of Michigan medical school. He was the founder and president of The Upjohn } \\
\text { Pharmaceutical Company. He was named Person of the Century by the Kalamazoo, Michigan } \\
\text { newspaper. }\end{array}$ \\
\hline Table I. Selected eponymous pharmaceutical companies (continued). \\
\hline
\end{tabular}

\section{REFERENCES}

1. Al Aboud A, Al Aboud K. From where did the names of dermatology drugs and brands come from? J Pakis Assoc Dermatol. 2008;18:165-6.

2. Abbott Laboratories. Wikipedia ${ }^{\circledR}$ [Internet]. Wikimedia Foundation. [Updated 24 July 2013; cited 29 July 2013]. Available from: http://en.wikipedia.org/wiki/Abbott_Laboratories 3. Bayer. Wikipedia ${ }^{\circledR}[$ Internet]. Wikimedia Foundation. [Updated 19 July 2013; cited 29 July 2013]. Available from: https://en.wikipedia. org/wiki/Bayer

4. Horta AM. [In memory of Friedrich Bayer on the centenary of his work.1863-1963]. Hospital (Rio J). 1964;65:1157-60.

5. Bristol-Myers Squibb. Wikipedia ${ }^{\circledR}$ [Internet]. Wikimedia Foundation. [Updated 18July 2013; cited 29 July 2013]. Available from: http://en.wikipedia.org/wiki/Bristol-Myers_Squibb 6. Worthen DB. Edward Robinson Squibb (1819-1900): advocate of product standards. J Am Pharm Assoc (2003). 2006;46:754-8.
7. Eli Lilly and Company. Wikipedia ${ }^{\circledR}$ [Internet]. Wikimedia Foundation. [Updated 11July 2013; cited 29 July 2013]. Available from: http://en.wikipedia.org/wiki/Eli_Lilly_and_Company 8. Johnson \& Johnson. Wikipedia ${ }^{\circledR}$ [Internet]. Wikimedia Foundation. [Updated 18July 2013; cited 29 July 2013]. Available from: https:// en.wikipedia.org/wiki/Johnson_\%26_Johnson

9. Al Aboud KM. Robert Wood Johnson I: a businessman's contribution to medicine and dermatology. Dermatol Nurs. 2009;21:234.

10. Pfizer. Wikipedia ${ }^{\circledR}$ [Internet]. Wikimedia Foundation. [Updated 20 June 2013; cited 29 July 2013]. Available from: http:// en.wikipedia.org/wiki/Pfizer

11. Pierre FABRE. Wikipedia ${ }^{\circledR}$ [Internet]. Wikimedia Foundation. [Updated 27 July 2013; cited 29 July 2013]. Available from: http:// fr.wikipedia.org/wiki/Pierre_Fabre

12. William E. Upjohn. Wikipedia ${ }^{\circledR}$ [Internet]. Wikimedia Foundation. [Updated 27 May 2013; cited 29 July 2013]. Available from: http://en.wikipedia.org/wiki/William_E._Upjohn 